\title{
A Call for Barriers in Implementation of Education Regulation: the Latest English Textbook as Main Instructional Media in Schools in Indonesia
}

\author{
Fadel Muslaini*; Diah Kristina; Ngadiso Ngadiso \\ Sebelas Maret University, Surakarta, Indonesia \\ Email: fadelmuslaini@yahoo.com
}

http://dx.doi.org/10.18415/ijmmu.v5i4.170

\begin{abstract}
Education in Indonesia is much influenced by the implementation of the latest curriculum namely 2013 curriculum with integrated skills approach. The implementation condition must be overseen through time to measure how effective the progress and the result are. To find out the condition, this study involved the teacher and students in the implementation of this issue to find out their perspective and their experience in the real condition of learning process. This paper explores the significant impact of implementation policy in the textbook in Indonesia as the main instructional media applied in the entire country. This study on the other hand tried to reveal the authentic condition in the process of learning and teaching by focusing on English materials. Both quantitative and qualitative methods were used in the process of data collection. This research found many barriers faced by the teacher and students in the policy implementation of textbook in the school as the national sample. The special purposes and the local situation influenced a lot the impact of this country-scale regulation. This study result is expected to provide additional information and evidence to fulfill the aim of the learning process effectively in the future that will be beneficial for authority of education policy, teachers, students, organization, and etc.
\end{abstract}

Keywords: Regulation; Implementation; English Textbook; Indonesian Curriculum, Instructional Media;

\section{Introduction}

Since 2013, Indonesian Education and Culture Ministry have begun implementing a new curriculum in every school in the entire country. In relation to that condition, not only the way of teaching is provided but also the instructional media are presented to aid teachers in transferring the material for each subject. Especially in English subject, almost every school until this year, 2018, still utilizes the same textbook as the main resource of learning and teaching (Mukundan, Nimehchisalem, \& Hajimohammadi., 2011). As a part of the materials used in the language classroom, the textbook can often play a crucial role related to students' success or failure. Meanwhile, if this situation is compared to the general learning resource in advanced country, textbook as the media must be supported by other instructional media with technological function to boost the process of achieving education goals. Meanwhile, the implementation of the latest Indonesian curriculum does not really provide or support the opportunity. Newby (2011) states that computer or any device could be a teacher or assistance that is functional to provide materials in evaluating the students' response and to give feedback to students 
including assessment. In addition, Lankshear \& Knobel (1997) and Jones \& Hafner (2011) state that the learning opportunities with technological support are more likely to be interactive, social, and multimodal.

Nowadays, in the era of computerization, technological products provide many options to aid teacher and students for learning process in the classroom, but that opportunity has not been optimized in Indonesia. Arsyad (2010) states that any technological devices possess an ability to stimulate the students' intention to learn and do the assignment because the animation, graphic, color, and music will provide realism. Computer based or mobile learning is for instance a possible option that might potentially give impact on the improvement of learning achievement in which it provides flexible and motivational instructional media. Harmer (2007) states that software and hardware are parts of instructional media becoming vital components in using computer-based technology.

Meanwhile, the application of device-based technology or so-called multimedia in learning will enable the teacher to convey a great amount of information to the students (Blythe-Lord, 1991, Kemp \& Smellie, 1989, and Wittich \& Schuller., 1973). Those options are not only beneficial in one side but also the other side. The usage of the instructional media supports the out-of-class learning and students' center learning or dependent learning as the main focus educational concept in this decade. There are two important dimensions for successful second language learning. They are what goes on inside the classroom and what goes on outside of the classroom (Richard., 2014). Comparing to Education in Indonesia, the power of out-of-class learning which has been observed depicts that young people in the northern European countries, such as Finland and Denmark, have good language skills and are often quite fluent in English compared to their counterparts in countries such as Portugal and Italy (Richard., 2014).

The basic role of this study is to reveal the real condition happening in the classroom based on the actual experience and perspective from the English teacher and students. Evaluation is a matter of judging the fitness of something for a particular purpose. Evaluation is concerned with relative merit. There is no absolute good or bad-only degree of fitness for the required purpose (Hutchinson \& Waters., 1986). The purpose of this study is also to find out the ideal condition between the authorized party in controlling the educational system through management and the field party as the front people in maintaining and applying the curriculum decided previously especially in the implementation of instructional media. Without revealing this issue, there will be no further reflection or data in what aspect the instructional media should be maintained, and in what aspect the instructional media should be changed or removed. In the process of implementation, the data collected previously will also be very useful for other party that deals with educational field especially one focusing on improving instructional media.

\section{Research Problem}

In every region or country, designing a curriculum as the core of the education concept will be one of the crucial parts in developing a better educational outcome. Creating or providing a good curriculum with the entire component in it is not enough to build a better education. The other important part is the implementation and the evaluation. Jangangard (2007) states that one of the ways to improve curriculum is to improve the textbook and the materials employed in the program. Meanwhile in Sheldon (1998), we need to evaluate textbooks for two reasons. First, the evaluation will help the teacher or program developers in making decisions on selecting the appropriate textbook. Second, the evaluation of merits and demerits of textbook will familiarize the teacher with its probable weaknesses and strengths. If we focus on the implementation of one of the components in curriculum implementation such as the media, we must join and observe in the real situation where the media are applied. The school as the main setting where the instructional media are applied should be observed seriously to take all the necessary data in the process of implementation. 


\section{Research Focus}

The main focus on this study is to find out the contradiction between the ideal condition that is intended to be created and the real situation happened in a school in implementing the instructional media. Cunningsworth (1995) states that no course book designed for a general market will be absolutely ideal for particular group of learners. If there is a contradiction in the real field, the researcher will subcategorize or clarify the aspects which are related with the contradiction and which one is not. The data taken as the contradiction information or not is possibly taken as the data to provide improvement in the future regulation or implementation.

\section{Theoretical Framework}

\section{A. Instructional Media}

Instructional media is the fundamental tool to deliver the material effectively and efficiently. The success of the learning outcome is much influenced by the type of the instructional media applied in the learning process in the classroom. All the facility, teacher's competence and students' intention should be taken as the consideration in which the instructional media should be applied. For instance, a school with availability of internet connection is possible to provide learning material with internet based or online based instructional media. Richards (2002) states that it is quite easy to develop instructional media for school which provide internet access. In reverse, a school with no advance technology applied in it should be given more chance to provide different types of instructional media connected with learning outside of classroom or natural learning concept with creative instructional media.

\section{B. Textbook}

Brown (1994) states that the most obvious and common form of material supports for language instruction comes through textbooks. Richard (2001) points out that textbook share the key component of language teaching serving as the basis for much of the language input learners receive when learning a language. A good media that fits the students' or the teachers' need does not always bring a success in the final outcome, it happens by the influence of the capability and real commitment of the instructor or the teacher in optimizing all the function of the instructional media while considering also all do's and don'ts in using the instructional media. A good instructional media is not only possible to use in the classroom but also outside the classroom even there is no instructor in helping how to operate the media in spite of the easy way to operate the media in order for everyone could use it anywhere and anytime. In order to account for the roles of effective teaching and learning, the evaluator must gain an awareness of the learner and teacher's needs and interests (Bell \& Gower., 1998). In other hand, an expected media should also be applied based on the students' need and interest to provide a motivation in gaining the objective of learning and experience it not as a burden but as enjoyable moment. The model of instructional media is not about how advanced or how great the instructional media could look like, but it is all about how effective and efficient the implementation of the instructional media in a school is.

\section{Implementation and Evaluation}

Karamouzian (2010) also states that textbooks are seen as central to teaching and learning, as their quality is a determining factor in enhancing or diminishing the quality of a language program. In every condition of implementation of instructional media, there should be several struggle or problem starting from the basic until the unpredictable one. (Davies., 2002) Evaluation is measuring of strengths and weakness. In addition, (Mukundan., 2010) there are two main reasons why textbooks are evaluated; 
the first which is associated to the task of textbook selection (predictive evaluation) and the second to the need to evaluate it while in use (retrospective evaluation) so that teachers can implement adaptation procedures later. This does not mean that the implementation is not totally successful but it could mean that there are unpredictable things that will influence the process of implementation. Our role here is to find the area of contradiction and find the solution how to overcome that problem.

In evaluating textbooks, several researchers, educators, and reading specialist provide checklists as a tool to judge (Cunningsworth, 1995). Cunningsworth (1995) suggests a checklist as follows: 1) aims and approach; 2) design and organization; 3) language content; 4) skills; 5) topic; 6) methodology; 7) teacher's books, and 8) practical consideration. In other perspective, Harmer (1998) proposes nine main areas to evaluate the textbooks; 1) price; 2) availability; 3) layout and design; 4) methodology; 5) skills; 6) syllabus; 7) topic; 8) stereotyping; and 9) teacher's guide. Meanwhile, Skierso's (1991) checklist considers the characteristics related to 'bibliographical data', 'aims and goals', 'subject matter', 'vocabulary and structures', 'exercises and activities', and 'layout and physical makeup'.

\section{Methodology}

This research provides a qualitative and quantitative character. Quantitative scales have the merit of allowing an objective evaluation of a given textbook through Likert style rating scale (Skierso., 1991). Cunningsworth (1995) suggests that it is important to limit the number of criteria used, the number of questions asked, to manageable proportions, otherwise we risk being swamped in a sea of details. Qualitative scale, on the other hand often use open-ended questions to elicit subjective information on the quality of course book in depth evaluation (Richards., 2001). Meanwhile, (Mukundan et al., 2011) qualitative method allows the developer to gain a deep understanding of the construct under investigation. This study was conducted in the period of October 2017. A systematic collection of the data was employed, as presented below.

\section{Instruments and Procedures}

In this study, the data collection consisted of the analysis and identification of the condition by providing an interview, a questionnaire, an observation, and a document analysis. To find the first real condition the researcher provided an interview to carry out as much as information from the teacher as the core point in implementing the instructional media. Interview here conveyed open questions to gain possible information including the unpredictable one. Started from the general question about the condition of the media until the questions about the expectation of the teacher about the media, 36 questions were inputted in the interview time. The second instrument is a questionnaire to carry out more information from the students' perception or attitude in implementing instructional media in the classroom. The type of the questionnaire is Likert scale category to provide a consistence answer or data from the participant. The stance of the questionnaire will be used as the reflection to take the valid data of the real condition in the implementation of the instructional media. As the third way of collecting the data, document analysis was employed to reveal the actual appearance of the instructional media (textbook) from one aspect to another aspect that will reveal supportive information to the findings. The fourth way of collecting the data which is observation, joining in the real situation (classroom) where the instructional media implemented in the learning process was the other source to support all the information gained previously to find an intact condition of the implementation. 


\section{A. Participants}

(Mukundan et al., 2011) According to the ideal criteria, evaluators like teachers, researchers as well as students can rate the quality of the material of the textbook. In this research, English teacher is the main focus of the interview activity from a school which implemented the instructional media. 6 Students were from several classes as the representative based on their level of intelligence to gain the information from the students' perspective and attitude through questionnaire. Researcher was also the observer in the implementation of the instructional media and as the analyzer in revealing the content of the document (textbook) comparing with the answer of the interview question and the choice in the questionnaire from the students and the teacher.

\section{B. Data Collection and Analysis}

The data from different instruments were collected and transcribed to compare the entire information one by one. The relevant information was then taken as the valid information and the irrelevant information was then considered as the invalid information until there is a further explanation of the different perspective or attitude or condition in the implementation. In the end of the process of the data analysis, point by point were created to underline some fundamental information related to the result of the research.

\section{Result}

Based on the data collection and data analysis, several information or points can be gained or revealed with the following: 1) Most students felt that the textbook was in good criteria to be applied in the classroom; 2) Teacher explained that the book was not related to the concept of students center overall, and out of class learning was not really provided effectively and efficiently in applying the current instructional media; 3) Based on the observation, several school facilities were possible supports for additional or supportive instructional media that will aid students in understanding the target material of each subject. Meanwhile, researcher also found that most students use smartphone but not in the teaching and learning time; 4) No concept of mobile learning while in this era it is more possible and effective than conventional instructional media.

\section{Discussion}

(Munir., 2013) mentions that the textbook should ideally be designed to achieve several expected goals. In this research, the data collected from various sources and subjects made it possible to reveal the real condition in the implementation of the instructional media. The researcher also revealed a gap between the ideal condition of the implementation of the instructional media (textbook) and the real situation based on the experience of the teacher and the students. However, there were still several contradictions in which the condition and specific need of every school is not the same and the facility of the school is different either where the teacher can take the conditional advantage of the situation not just in general concept.

The result suggest that several contradiction or weaknesses should be taken as further consideration to provide better condition in the following occasion especially in the implementation of the instructional media that will help students and teacher based on their different needs and intentions in the learning process effectively and efficiently. This study found that both students and teacher at Surakarta approved the implementation of English instructional textbook as good media but still need to improve in 
any aspect related to the purpose in providing student-centered concept of learning, and out-of-class learning in which it is believed more effective. With the existing space to provide creative idea, it is truly helpful for teacher to develop material based on the students' need and current issue.

Technological touch is necessary to motivate the students in learning not only in the classroom and outside the classroom. The burden of English teacher is too many while they are expected to educate many students almost every day. Other regulation or revision regulation is intended to decrease unnecessary task or to create new innovation in education that will provide enjoyable and interesting process of learning.

\section{Conclusion}

The implementation of the instructional media is intended to provide a better environment in the learning process. Each school as the field of the implementation has a different need and situation that could influence the learning outcome that could come from many aspects. Generalizing type of the instructional media could provide effective implementation, but in reverse there should also be a space or additional change to the teacher and the students to choose the best and fit material based on their need and intention. The use of advance technology in this era is also possible in delivering learning material to provide creativity and increasing students' motivation and curiosity in pursuing the aim of the education in each school. In the result of this study, the researcher provided the real situation in implementation of English textbook as consideration in any parties to improve the quality of education each year in regionally in Indonesia especially or other countries globally.

\section{Acknowledgment}

The researchers gratefully acknowledge the funding support received for this project from Indonesia Endowment Fund for Education (LPDP) Scholarship.

\section{References}

Arsyad, A. (2010). Media Pembelajaran. Jakarta: Raja Grafindo Persada.

Bell, J. \& Gower, R. (1998). Writing course materials for the world: A great compromise, In B. Tomlinson (ed.). Material Development in Language Teaching (p. 116-129). Cambridge: Cambridge University Press.

Blythe-Lord, R. (1991). The Educational Media Design Handbook. London: Macmillan.

Cunningsworth, A. (1995). Choosing your coursebook. Oxford: Heinemann.

Davies, P., \& Pearce, E. (2002). Success in English Teaching. New York: Oxford University Press.

Harmer, J. (1998). How to teach English. Harlow, Essex: Addison Wesley Longman.

Harmer, J. (1998). How to Teach English: An Introduction to the Practice of English Language Teaching. Harlow, UK: Longman.

Harmer, J. (2007). How to teach English. China: Pearson Longman. 
Jahangard, A. (2007). Evaluation of EFL Materials Taught at Iranian Public High Schools. The Asian EFL Journal, 9(2): 151-169.

Karamouzian, F. M. (2010). A Post-Use Evaluation of Current Reading Comprehension Textbooks Used in TEFL Programs. The Iranian EFL Journal, 6(4): 24-62.

Lankshear, C., Knobel, M. (1997). Different words? Technology-mediated classroom learning and students' social practices with new technologies in home and community settings. In: Lankshear C. et al. (eds), Changing Literacies. Buckingham: Open University Press.

Mukundan, J. (2010). Retrotext- E 1.0: The Beginnings of Computer-based ELT Textbook Evaluation. Advances in Language and Literary Studies, 1(2): 270-280. https://doi.org/10.7575/aiac.alls .v.1n.2p.270.

Mukundan, J., Nimehchisalem, V., \& Hajimohammadi, R. (2011). Developing an English Language Textbook Evaluation Checklist: A Focus Group Study. International Journal of Humanities and Social Science, 1(12): 100-106. https://doi.org/10.19030/cier.v4i6.4383.

Munir, S. (2013). An Evaluation of the Reading Comprehension Textbooks Taught At the English Education Department of Islamic Higher Education in West Sumatera. Qudus International Jurnal of Islamic Studies, 1(1): 59-75.

Newby, T. J., et al. (2011). Educational Technology for Teaching and Learning 4th Edition. Boston: Pearson Education, Inc.

Richards, J. C. (2014). The Changing face of Language Learning: Learning Beyond the Classroom. RELC Journal 1(18). Australia: Sage Publisher.

Richard, J. C. (2001). Curriculum Development in Language Teaching. Cambridge: Cambridge University Press.

Skierso, A. (1991). Textbook selection and evaluation. In M. Celce-Murcia. Teaching English as a second or foreign language (p. 432-452). ( ${ }^{\text {nd }}$ Ed.). Boston: Heinle \& Heinle Publishers.

\section{Copyrights}

Copyright for this article is retained by the author(s), with first publication rights granted to the journal.

This is an open-access article distributed under the terms and conditions of the Creative Commons Attribution license (http://creativecommons.org/licenses/by/4.0/). 